\title{
Evaluasi Implementasi eGovernment Pada Situs Web Pemerintah Kota Surabaya, Medan, Banjarmasin, Makassar dan Jayapura
}

\author{
Melkior N. N. Sitokdana \\ Pascasarjana Teknik Elektro, Universitas Gadjah Mada, Yogyakarta \\ Jl. Grafika No.2, Yogyakarta 55281 \\ E-mail: sitokdanamelkior@gmail.com
}

Masuk: 29 April 2015; Direvisi: 1 Juni 2015; Diterima: 1 Juni 2015

\begin{abstract}
Evaluating the Implementation eGovernment for the website of cities such as Surabaya, Medan, Banjarmasin, Makassar and Jayapura. This study is conducted to evaluate the eGovernment Websites in developed cities representing major islands in Indonesia. The evaluation are focused on the Transparency, Service, Efficiency, Economy, Aspirations, Display, Update and Stages Achievement of the eGovernment according to the World Bank Group. This study uses descriptive and qualitative methods by reviewing the literature on the papers that have been published, reviewing the legislation, to collect information through print and electronic media. The results of the evaluation of the implementation of eGovernment sites show that Surabaya is far better than other cities. These results together with the evaluation of the 2012-2014 PeGi ratings that the eGovernment site has been dominated by the governments on the island of Java.

Keywords: eGovernment, Website, Services, Information
\end{abstract}

\begin{abstract}
Abstrak. Penelitian ini dilakukan untuk mengevaluasi situs web eGovernment di kotakota maju mewakili pulau-pulau besar di Indonesia, yakni: Surabaya, Medan, Banjarmasin, Makassar dan Jayapura. Evaluasinya dari sisi Transparansi, Layanan, Efisiensi, Ekonomi, Aspirasi, Tampilan, Update dan Tahapan Pencapaian Tujuan EGovernment menurut World Bank Group. Penelitian ini menggunakan metode kualitatif deskriptif, yakni dengan melakukan kajian literatur terhadap paper-paper yang sudah diterbitkan, kajian peraturan perundang-undangan, menghimpun informasi melalui media cetak dan elektronik. Hasil evaluasi implementasi situs eGovernment menunjukkan bahwa Kota Surabaya jauh lebih baik dibanding Kota-kota lainnya. Hasil ini sama dengan evaluasi PeGi dari tahun 2012-2014 bahwa dalam pemeringkatan Situs Web eGovernment selama ini hanya didominasi oleh pemerintahan di pulau Jawa.
\end{abstract}

Kata Kunci: eGovernment, Situs Web, Layanan, Informasi

\section{Pendahuluan}

Di era yang serba canggih dan terbuka ini penggunaan teknologi informasi dan komunikasi di lingkungan pemerintahan dan lembaga publik merupakan suatu keharusan yang tidak dapat ditawar lagi karena teknologi informasi terbukti dapat meningkatkan kualitas layanan yang lebih responsif, efektif, efisien dan akuntabel. Untuk itu pemerintah telah merespon positif dan mewajibkan seluruh pemerintahan dan lembaga publik memanfaatkan teknologi informasi untuk kepentingan pelayanan publik dan administrasi pemerintahan, dengan mengeluarkan beberapa kebijakan sebagai payung hukumnya, yakni Instruksi Presiden No 3 tahun 2003 tentang Kebijakan dan Strategi Nasional Pengembangan eGovernment, UU No.11 Tahun 2008 tentang Informasi dan Transaksi Elektronik (UU ITE), UU No.14 Th.2008 tentang Keterbukaan Informasi Publik (UU KIP), Undang-Undang Nomor 19 Tahun 2002 tentang HaKI, dan Undang-Undang Nomor 32 Tahun 
2004 Tentang Pemerintah Daerah. Dengan dasar itulah pemerintah dan lembaga publik telah gencar mengembangkan dan memanfaatkan teknologi informasi dan komunikasi untuk kepentingan pelayanan publik dan administrasi internal. Dalam implementasinya, konten yang sering diutamakan adalah pengembangan dan pemanfaatan situs web eGovernment, namun dari sejumlah evaluasi yang dilakukan oleh Akademisi dan Auditor Internal pemerintahan berdasarkan indikator yang ditetapkan oleh Kementerian Komunikasi dan Informatika maupun World Bank menunjukkan bahwa mayoritas situs web eGovernment berada pada tingkat pertama (persiapan), hanya sebagian kecil yang telah mencapai tingkat dua (pematangan), sedangkan tingkat tiga (pemantapan) dan empat (pemanfaatan) belum tercapai (Sosiawan, 2008: 104). Hal tersebut dapat dimaklumi juga karena Indonesia menghadapi sejumlah kompleksitas masalah, misalnya ketidakmerataan sarana dan prasarana, rendahnya kualitas sumber daya manusia, angka kemiskinan tinggi, kondisi perekonomian yang tidak stabil, kondisi perpolitikan nasional semakin buruk, kinerja aparatur pemerintahan yang buruk, dan sebagainya. Tidak dipungkiri juga bahwa sejumlah hal tersebut diatas menjadi faktor penghambat dalam implementasi eGovernment, karena pada dasarnya pengembangan aplikasi eGovernment memerlukan pendanaan yang cukup besar, komitmen dari pengambil kebijakan, kesiapan dari sisi sumber daya manusia aparat pemerintahan, kesiapan dari masyarakat dan pihak bisnis.

Berdasarkan data yang diperoleh dari situs www.kemendagri.go.id, dipublikasikan pada bulan Juli 2013 bahwa dari 530 pemerintah daerah baik tingkat provinsi, kotamadya maupun kabupaten se-Indonesia terdapat 485 (92\%) situs web pemerintah daerah yang aktif, $25(5 \%)$ tidak ada situs resmi, 20 (4\%) situs web offline. Dari segi kuantitas perkembangan situs web pemerintah daerah memang meningkat pesat, namun dari segi kualitas masih belum terlalu baik, tidak semua situs web pemerintah daerah menyediakan fasilitas pelayanan publik yang berstandar, lebih banyak pemerintah daerah membuat situs semata-mata untuk memenuhi persyaratan tuntutan keterbukaan informasi publik tanpa adanya perubahan manajemen kerja pemerintahan yang berbasis pada elektronik. Untuk itu, penelitian ini dilakukan untuk mengevaluasi tingkat kualitas eGovernment pada situs web pemerintah daerah di beberapa kota yang dikategorikan "maju" berdasarkan pulaupulau besar di Indonesia. Pemilihan tempat kajian ini tidak didasarkan pada indikator tertentu, namun tidak dipungkiri bahwa beberapa daerah yang menjadi objek kajian ini telah mendapatkan penghargaan atas penggunaan eGovernment. Evaluasi ini mengkaji kualitas konten situs eGovernment dilihat dari beberapa indikator umum yakni: Transparansi, Layanan, Efisiensi, Ekonomi, Aspirasi, Tampilan, Update (Sitokdana, 2014), Tahapan Pencapaian Tujuan eGovernment (The World Bank, 2002).

Tidak sedikit yang melakukan evaluasi terhadap implementasi eGovernment, baik secara umum maupun khusus untuk situs web. Salah satunya adalah setiap tahun dilakukan Pemeringkatan eGovernment Indonesia (PeGi) oleh Ditjen APTIKA KEMKOMINFO RI (2014) terhadap implementasi eGovernment dari tingkat pusat hingga daerah, dengan tujuan hasil evaluasi dapat mendorong peningkatan pemanfaatan TIK di lingkungan pemerintah setelah melihat kelebihan dan kekurangan dari masing-masing pemerintah. Evaluasi pemerintah yang kontinyu ini menandahkan bahwa eGovernment diposisikan sebagai kebijakan strategis nasional, sehingga dibutuhkan kajian ilmiah oleh kalangan akademisi, agar hasilnya dapat direkomendasikan untuk perbaikan kedepan. Dengan langkah ini hasilnya dijadikan sebagai acuan dalam mengembangkan situs web eGovernment dimasa yang akan datang agar lebih tersistematis dan terarah sesuai dengan kebutuhan dan tuntutan perubahan. Lebih luas, hasil kajian dijadikan sebagai arahan strategis dalam pengambilan kebijakan, terutama dalam hal perancangan rencana strategis pengembangan eGovernment bagi daerah-daerah yang menjadi objek pengkajian ini, dan pada umumnya bagi daerah-daerah yang sedang dalam tahap persiapan pengembangan eGovernment. Dengan maksud pengembangan eGovernment lebih menyeluruh, tidak hanya sebatas pembangunan situs semata, tetapi lebih dari itu sehingga dibutuhkan perumusan kebijakan strategis yang holistik dan 
komprehensip disertai komitmen yang kuat dari semua stakeholders. Mengingat, kesuksesan eGovernment didukung oleh banyak hal, misalnya menurut (Indrajit, 2006:12) ada tiga hal, yakni pertama Support; adanya keinginan (political will) dari berbagai kalangan pejabat publik dan politik untuk benar-benar menerapkan e-Government. Disepakatinya kerangka eGovernment sebagai salah satu kunci sukses negara dalam mencapai visi \& misi bangsanya, dialokasikannya sejumlah sumber daya (manusia, finansial, waktu, tenaga, dll) disetiap tingkatan pemerintahan untuk membangun konsep ini, dibangunnya infrastuktur \& suprastruktur (UU, PP, aturan kerjasama dengan swasta, dll), sosialisasi eGovernment secara merata, kontinyu, konsisten, \& menyeluruh kepada birokrat \& masyarakat. Kedua Capacity: Ketersediaan sumber daya (khususnya sumber daya finansial), Ketersediaan infrastruktur TI, Ketersediaan SDM yg berkompeten. Ketiga Value: Jenis aplikasi eGovernment apa sajakah yg harus didahulukan pembangunannya agar memberikan value (manfaat) yang signifikan bagi masyarakat.

Selain itu, dibutuhkan manajemen perubahan karena dalam merencanakan, mengembangkan, dan mengimplementasikan konsep e-Government pada dasarnya adalah menjalankan sebuah manajamen transformasi (change management) yang cukup kompleks. Seperti diketahui bersama, kebanyakan orang sangat anti dengan perubahan (people do not like to change). Dengan kata lain, konsep implementasi e-Government harus disertai dengan sebuah strategi tranformasi yang baik dan efektif, terutama yang berkaitan dengan pemberian dan penawaran insentif-insentif baru, pembentukan struktur institusi yang mendukung lingkungan perubahan, penyiapan dana yang cukup dan investasi untuk pengembangan keahlian dan kompetensi SDM yang terlibat, dan lain sebagainya. Karena pada dasarnya perubahan akan sangat erat berkaitan dengan hal-hal semacam struktur organisasi, manusia dan budaya, kebijakan, prosedur, ketersediaan sumber daya, teknologi, dan hal-hal lainnya (Indrajit, 2006:19).

\section{Tinjauan Pustaka dan Landasan Teori \\ 2.1 Tinjauan Pustaka}

Penelitian mengenai Evaluasi Implementasi eGovernment bukanlah suatu hal baru yang dijadikan tema penelitian. Oleh karena itu, penulis menjadikan beberapa penelitian terdahulu sebagai bahan referensi komparatif atau tinjauan pustaka.

Tasmil (2013) melakukan pemeringkatan eGovernment di Kota Makassar yang mencakup 18 SKPD. Penelitiannya menggunakan indikator Pemeringkatan eGovernment Indonesia (PeGI),yakni dimensi perencanaan, kelembagaan, infrastruktur, kebijakan dan aplikasi. Data penelitian diperoleh dengan pendekatan kualitatif dan analisis data secara deskriktif. Hasil penelitian menunjukkan bahwa implementasi eGovernment di Kota Makassar dalam kategori belum baik. Berdasarkan hasil pemeringkatan eGovernment pada 18 SKPD hanya satu SKPD dengan kategori "Baik Sekali", tujuh kategori "Baik" dan selebihnya masih dalam kategori "Kurang" dan "Sangat Kurang". Pemerintah Kota Makassar diharapkan dapat melakukan perbaikan untuk implementasi eGovernment yang lebih baik.

Penelitian oleh Hermana (2011) bertujuan untuk mengevaluasi kinerja pelayanan publik melalui Situs Web pemerintah di Indonesia. Variabel penelitiannya adalah karakteristik dari layanan $w e b$, popularitas Situs Web, dan web metrik. Data sekunder dan primer dikerahkan untuk mengukur variabel tersebut. Analisis data difokuskan pada mengidentifikasi pandangan kesenjangan digital dari tingkat pemerintahan dan lokasi geografis Jawa dan luar Jawa. Hasil temuan menunjukkan bahwa diluar Jawa Situs Web provinsi lebih dominan daripada Situs Web kota atau kabupaten, sedangkan untuk Pulau Jawa, Situs Web kabupaten atau kota ini lebih dominan daripada web provinsi. Selanjutnya hal itu menunjukkan bahwa luar Jawa provinsi ini lebih baik dari kabupaten dan kota untuk halaman dan konten web-nya, sementara dipulau jawa kota dan kabupaten ini lebih baik dan populer. Penelitian ini menunjukkan juga bahwa ada kesenjangan digital antara Jawa dan luar Jawa untuk halaman web, inbound link dan lalu lintas. 
Pada penelitian oleh Irawan (2012), evaluasi yang dilakukan menggunakan Webqual, yang adalah satu metode pengukuran kualitas berdasarkan presepsi pengguna. Dari hasil analisis diberikan rekomendasi untuk mengubah penampilan situs menjadi lebih menarik, menambahkan lebih akurat, jelas, detail, dan up to date sehingga orang bisa mendapatkan informasi lebih cepat dari pemerintah daerah.

\subsection{Landasan Teori}

World Bank mendefinisikan eGovernment sebagai berikut: "eGovernment refers to the use by government agencies of information technologies (such as Wide Area Network, the Internet, and mobile computing) that have the ability to transform relations with citizens, businesses, and other arms of government”. Sedangkan menurut UNDP (United Nation Development Program) mendefinisikan eGovernment secara lebih sederhana, yaitu: "eGovernment is the application of Information and Communication Technology (ICT) by government agencies" (World Bank dalam Indrajit, 2002: 2).

Pengertian lain, Electronic government merupakan suatu proses sistem pemerintahan dengan memanfaatkan ICT (information, communication and technology) sebagai alat untuk memberikan kemudahan proses komunikasi dan transaksi kepada warga masyarakat, organisasi bisnis dan antara lembaga pemerintah serta stafnya. Sehingga dapat dicapai efisiensi, efektivitas, transparansi dan pertanggungjawaban pemerintah kepada masyarakatnya. Dengan konsep pengembangan menyangkut hubungan Government to Government $(G 2 G)$, Government to Business (G2B) dan Government to Citizen (G2C) (Hartono, 2010).

Sedangkan menurut Rusli (2004) dalam Holle (2011), secara konseptual, konsep dasar dari eGovernment sebenarnya adalah bagaimana memberikan pelayanan melalui elektronik (e-service), seperti melalui internet, jaringan telepon seluler dan komputer, serta multimedia. Melalui pengembangan eGovernment ini, maka sejalan dengan itu dilakukan pula penataan sistem manajemen informasi dan proses pelayanan publik dan mengoptimalkan pemanfaatan teknologi informasi dan komunikasi.

Untuk mengembangkan eGovernment, ada empat fase yang diusulkan oleh World Bank yakni Presence (kehadiran), Interaction (Interaksi), Transaction (Transaksi), dan Transformation (Transformasi) (The World Bank, 2002). Model yang hampir sama dikemukakan Gartner Research (Gupta, 2004:58) mengajukan model The Value Chain Of E-Service, yang menetapkan empat tahap yang secara khusus dikembangkan dalam konteks $e$-Governance.

Keempat fase pada Gambar 1 jika dikontekskan untuk pengembangan situs web eGovernment di Indonesia: (1) Kehadiran, yaitu memunculkan Situs Web daerah di internet. Dalam tahap ini, informasi dasar yang dibutuhkan masyarakat ditampilkan dalam Situs Web pemerintah. (2) Interaksi, yaitu web daerah yang menyediakan fasilitas interaksi antara masyarakat dan Pemerintah Daerah. Dalam tahap ini, informasi yang ditampilkan lebih bervariasi, seperti fasilitas download dan komunikasi E-mail dalam Situs Web pemerintah. (3) Transaksi, yaitu web daerah yang selain memiliki fasilitas interaksi juga dilengkapi dengan fasilitas transaksi pelayanan publik dari pemerintah. (4) Transformasi, yaitu dalam hal ini pelayanan pemerintah meningkat secara terintegrasi.

Keempat hal tersebut diatas biasanya digunakan juga sebagai variabel dalam menilai pengembangan E-Government. Selain itu masih banyak variabel yang digunakan baik untuk mengevaluasi eGovernment secara keseluruhan maupun secara khusus, misalnya evaluasi tentang kualitas situs eGovernment, yaitu: audience, content, interactivity, usability dan innovation (Indrajit, 2006:53). Variabel itu yang lebih banyak digunakan, namun pada penelitian ini menggunakan beberapa indikator, yaitu: Transparansi, Layanan, Efisiensi, Ekonomi, Aspirasi, Tampilan, Update (Sitokdana, 2014). Aspek Transparansi berhubungan dengan keterbukaan anggaran dan kebijakan pemerintah berupa program kerja atau regulasi yang dimuat di situs web 
sehingga masyarakat bisa dapat mengakses informasi. Aspek layanan berhubungan dengan jenis layanan/sistem informasi yang sudah di-online-kan sehingga masyarakat melakukan transaksi melalui situs web. Aspek Efiensi berhubungan dengan pelayanan yang murah, kecepatan dan kemudahan masyarakat dari layanan situs web. Aspek Ekonomi berhubungan dengan ketersediaan informasi mengenai potensi ekonomi, peluang investasi dan layanan untuk pengembangan ekonomi masyarakat dan mitra bisnis. Aspek Aspirasi berhubungan dengan ketersediaan fasilitas untuk menyampaikan aspirasi atau komunikasi dengan pemerintah. Aspek tampilan berhubungan dengan pengaturan tampilan situs web, terutama untuk kemudahkan dan kenyamanan dalam akses informasi dan bertransaksi. Aspek Update berhubungan dengan kontinuitas ketersediaan berita/informasi penyelenggaraan pemerintahan.

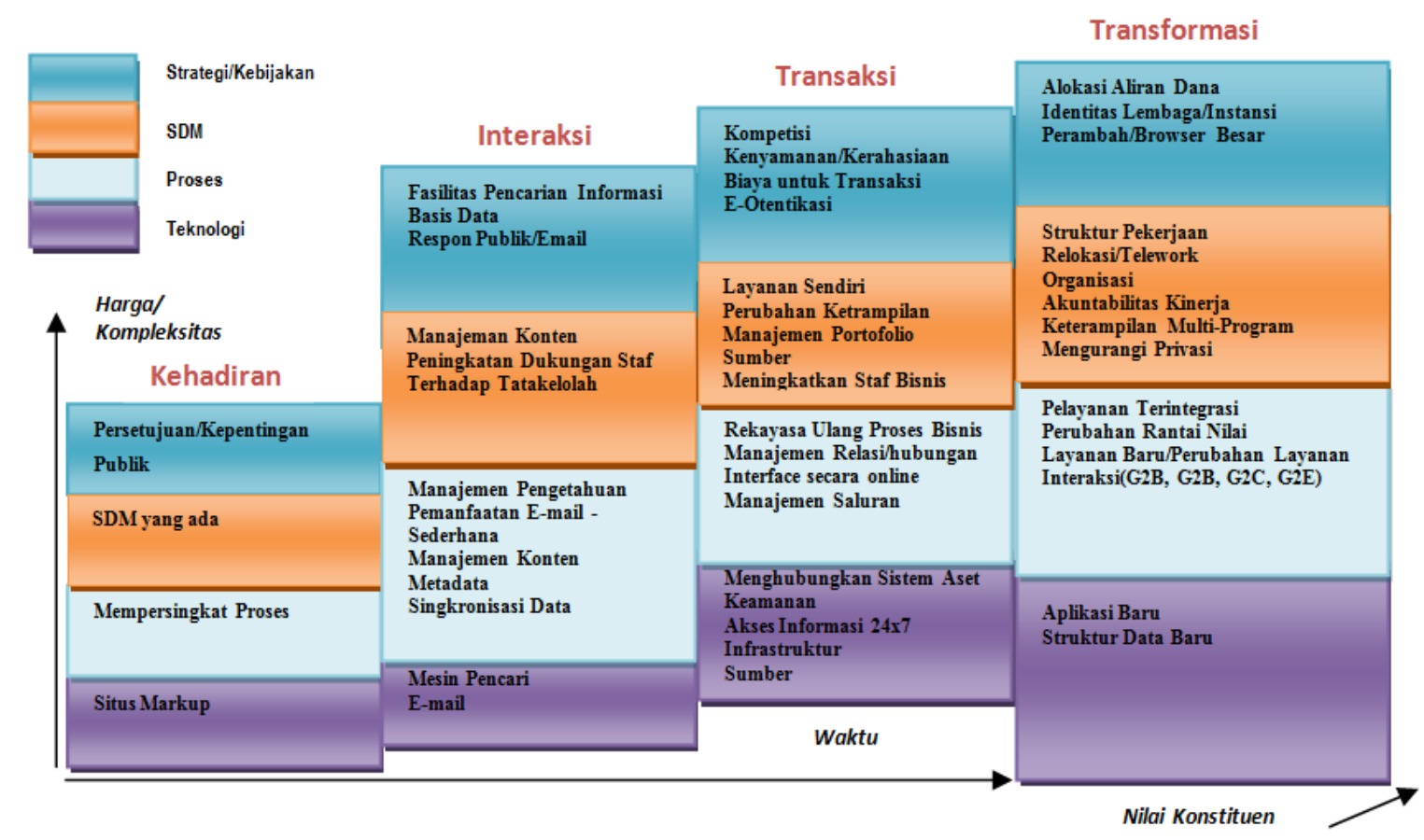

Gambar 1. Roadmap eGovernment (The World Bank, 2002)

Sebelum mengembangkan dan memanfaatkan eGovernment seperti rekomendasi World Bank diatas terlebih dahulu menyiapkan sejumlah hal, misalnya menurut INPRES No.3 Th.2003 aspek-aspek yang perlu dipersiapkan adalah: (1) E-Leadership; aspek ini berkaitan dengan prioritas dan inisiatif pemimpin dalam mengantisipasi dan memanfaatkan kemajuan teknologi informasi. (2) Infrastruktur Jaringan Informasi; aspek ini berkaitan dengan kondisi infrastruktur telekomunikasi serta akses, kualitas, lingkup, dan biaya jasa akses. (3) Pengelolaan Informasi; aspek ini berkaitan dengan kualitas dan keamanan pengelolaan informasi, mulai dari pembentukan, pengolahan, penyimpanan, sampai penyaluran dan distribusinya. (4) Lingkungan Bisnis; aspek ini berkaitan dengan kondisi pasar, sistem perdagangan, dan regulasi yang membentuk konteks bagi perkembangan bisnis teknologi informasi, terutama yang mempengaruhi kelancaran aliran informasi antara pemerintah dengan masyarakat dan dunia usaha, antar badan usaha, antara badan usaha dengan masyarakat, dan antarmasyarakat. (5) Masyarakat dan Sumber Daya Manusia, aspek ini berkaitan dengan difusi teknologi informasi didalam kegiatan masyarakat baik perorangan maupun organisasi, serta sejauh mana teknologi informasi disosialisasikan kepada masyarakat melalui proses pendidikan. 


\section{Metode Penelitian}

Penelitian ini menggunakan metode kualitatif deskriptif. Metode ini bertujuan untuk mendeskripsikan apa-apa yang saat ini berlaku. Di dalamnya terdapat upaya mendeskripsikan, mencatat, analisis dan menginterpretasikan kondisi yang sekarang ini terjadi atau ada. Dengan kata lain penelitian deskriptif kualitatif ini bertujuan untuk memperoleh informasi-informasi mengenai keadaan yang ada (Mardalis, 1999: 26). Biasanya penelitian deskriptif kualitatif dirancang untuk mengumpulkan informasi tentang keadaan-keadaan nyata sekarang yang sementara berlangsung (Convelo, 1993: 71). Penelitian kualitatif deskriptif dalam konteks penelitian ini bertujuan untuk mendeskripsikan, menganalisis dan menginterpretasikan kondisi eGovernment pada Situs Web Pemerintah Kota Surabaya, Kota Medan, Kota Banjarmasin, Kota Makassar dan Kota Jayapura menggunakan variabel Transparansi, Layanan, Efisiensi, Ekonomi, Aspirasi, Tampilan, Update (Sitokdana, 2014), Tahapan Pencapaian Tujuan EGovernment menurut World Bank Group (Indrajit, 2002).

Penelitian menggunakan sumber data sekunder, yaitu kajian terhadap literatur, artikel, jurnal serta situs di internet yang berkenaan dengan penelitian yang dilakukan (Sugiyono, 2009). Semuanya diakses atau kumpulkan melalui internet dan buku-buku tentang eGovernment dan metode penelitian. Lebih khusus untuk pembahasan dilakukan kajian terhadap konten situs web dari semua kota yang menjadi objek dalam penelitian ini. Penelitian dilakukan sendiri tanpa melibatkan pihak lain, baik dari proses penentuan judul, variable, metode dan analisis, namun peneliti yakni bahwa hasil studi ini dapat dipercaya dan layak dikonsumsi publik.

\section{Pembahasan}

Berdasarkan data Kementerian Dalam Negri pada tahun 2013 menunjukkan bahwa dari 530 pemerintah daerah tingkat provinsi, kotamadya dan kabupaten se-Indonesia terdapat 485 (92\%) situs web pemerintah daerah yang aktif, 25 (5\%) tidak ada situs resmi, 20 (4\%) situs web offline. Sejumlah situs yang aktif ditemukan memiliki tampilan monoton atau tidak user friendly, isi berita seadanya dan kadaluarsa atau sudah diperbaiki tapi isinya tidak menunjukkan substansi layanan transaksi dan informasi publik, tidak adanya interaksi antara pengunjung dan penyedia layanan, dan sebagainya. Gambaran ini ditemukan juga pada penelitian Rokhman (2008) bahwa situs Situs Web pemerintah daerah yang dibangun seadanya tanpa memperhatikan acuan seperti yang dituangkan dalam buku panduan sehingga situs web hanya sebatas proyek tanpa ada pengelolaan lebih lanjut, dan itu yang terjadi pada situs web pemerintah diseluruh Kabupaten di Jawa Tengah. Situs web pemerintah kabupaten sebagian besar sebatas menampakkan informasi, belum menunjukkan tahapan interaksi maupun transaksi.

Keadaan yang lebih parah dapat dijumpai pada pemerintahan di pulau Kalimantan, NTT, Sulawesi, Maluku dan Papua dalam hal pengembangan dan implementasi eGovernment termasuk didalamnya adalah situs web, Hal tersebut tercermin dari data Pemeringkatan eGovernment Indonesia (PeGI) tingkat Provinsi tahun 2012-2014 dilihat dari indikator Kebijakan, Kelembagaan, Infrastruktur, Aplikasi dan Perencanaan, yakni: tahun 2012 semua Provinsi dari sejumlah daerah/pulau yang disebutkan diatas pada kategori "Kurang" dan "Sangat Kurang" hanya Provinsi Gorontalo yang kategori "Baik". Tahun 2013 hanya Provinsi Gorontalo, Papua dan Kalimantan Tengah pada kategori "Baik. Sedangkan tahun 2014 hanya Provinsi Gorontalo yang mendapatkan kategori "Baik". Dengan demikian, data ini menunjukkan bahwa pengembangan dan implementasi eGovernment disejumlah daerah/pulau tersebut masih sangat kurang dibanding Provinsi di pulau Jawa dan Sumatra jika dilihat dari data peringkat 10 besar PeGi tahun 2012-2014 (Ditjen APTIKA KEMKOMINFO RI, 2014)

Terlepas dari itu, ada juga pemerintah daerah yang mengklaim telah mengaplikasikan eGovernment, namun kenyataannya implementasi melalui situs web daerah belum didukung oleh sistem manajemen dan proses kerja yang efektif karena kesiapan peraturan, prosedur dan 
keterbatasan sumber daya manusia (Sosiawan, 2008: 99). Kondisi demikian masih dijumpai juga didaerah-daerah yang kategori sudah maju, sehingga masyarakat dan pihak bisnis masih merasa informasi yang ditampilkan di situs web belum memenuhi pelayanan prima yang didengungdengungkan pemerintah selama ini. Untuk itu, penelitian ini lebih mengkaji pada kota-kota maju mewakili setiap pulau di Indoensia agar dilihat keberhasilan atau capaian dari masing-masing daerah. Evaluasi dilakukan pada sisi konten berdasarkan beberapa indikator, yakni dari sisi transparansi, layanan, efisiensi, ekonomi, aspirasi, tampilan, update, (Sitokdana, 2014) dan tahapan pencapaian tujuan eGovernment (The World Bank, 2002). Pada Tabel 1 sampai dengan Tabel 8 dirangkum hasil evaluasi berdasarkan penelusuran situs web pada daerah-daerah yang menjadi objek kajian.

Tabel 1. Evaluasi Situs Web eGovernment Sisi Transparansi

\begin{tabular}{|c|c|c|c|c|c|}
\hline \multirow{9}{*}{ Transparansi } & Surabaya & Medan & Banjarmasin & Makassar & Jayapura \\
\hline & Situs Web Pemerintah & Situs Web & Situs Web & Situs Web & Situs Web kota \\
\hline & kota Surabaya telah & Pemerintah kota & Pemerintah kota & Pemerintah kota & Jayapura Belum \\
\hline & memasukkan Laporan & Medan telah & Banjarmasin telah & Makassar telah & memasukan \\
\hline & Pengelolaan Anggaran & memasukkan & memasukkan & memasukkan & Laporan \\
\hline & dan Rencana Program & Laporan & Laporan & Laporan & Pengelolaan \\
\hline & & Pengelolaan & Pengelolaan & Pengelolaan & Anggaran dan \\
\hline & & Anggaran dan & Anggaran dan & Anggaran dan & Rencana Program \\
\hline & & Rencana Program & Rencana Program & Rencana Program & \\
\hline
\end{tabular}

Tabel 2. Evaluasi Situs Web eGovernment Sisi Layanan

\begin{tabular}{|c|c|c|c|c|c|}
\hline & Surabaya & Medan & Banjarmasin & Makassar & Jayapura \\
\hline Layanan & $\begin{array}{l}\text { Tersedia layanan } \\
\text { pelayanan publik, } \\
\text { pelayanan media center } \\
\text { atau layanan aspirasi, } \\
\text { pelayanan perizinan dan } \\
\text { pelayanan informasi. } \\
\text { Semua proses dilakukan } \\
\text { secara transaksi online } \\
\text { tidak hanya sebatas } \\
\text { informasi }\end{array}$ & $\begin{array}{l}\text { Layanan yang } \\
\text { diberikan berupa } \\
\text { informasi prosedur } \\
\text { layanan dan } \\
\text { transaksi secara } \\
\text { online. Salah satu } \\
\text { layanan yang bisa } \\
\text { dilakukan secara } \\
\text { online adalah } \\
\text { pendaftaran Akta } \\
\text { Kelahiran }\end{array}$ & $\begin{array}{l}\text { Layanan yang } \\
\text { diberikan berupa } \\
\text { informasi prosedur } \\
\text { layanan dan } \\
\text { transaksi secara } \\
\text { online. }\end{array}$ & $\begin{array}{l}\text { Layanan yang } \\
\text { diberikan berupa } \\
\text { informasi prosedur } \\
\text { layanan dan } \\
\text { transaksi secara } \\
\text { online. Misalnya } \\
\text { sistem informasi } \\
\text { ePuskesmas, Portal } \\
\text { Smart City, } \\
\text { Udoctor, E-Gallery, } \\
\text { Perizinan Online, } \\
\text { dsb. }\end{array}$ & $\begin{array}{l}\text { Layanan yang } \\
\text { diberikan masih } \\
\text { berupa informasi } \\
\text { namun belum } \\
\text { menyentuh kepada } \\
\text { layanan publik }\end{array}$ \\
\hline
\end{tabular}

Tabel 3. Evaluasi Situs Web eGovernment Sisi Efisiensi

\begin{tabular}{|c|c|c|c|c|c|}
\hline & Surabaya & Medan & Banjarmasin & Makassar & Jayapura \\
\hline Efisiensi & $\begin{array}{l}\text { Sejumlah layanan yang } \\
\text { ada tentunya akan } \\
\text { meningkatkan kecepatan, } \\
\text { ketepatan dan } \\
\text { kemudahan. Salah satu } \\
\text { layanan yang } \\
\text { diunggulkan adalah } \\
\text { layanan } \text {-procurement, } \\
\text { terbukti sudah } \\
\text { tersertifikasi ISO } 27001\end{array}$ & $\begin{array}{l}\text { Informasi layanan } \\
\text { masyarakat, } \\
\text { layanan umum, } \\
\text { layanan bisnis, } \\
\text { layanan oleh } \\
\text { badan pelayanan } \\
\text { perijinan terpadu } \\
\text { dapat } \\
\text { mengefisiensikan } \\
\text { waktu dan biaya } \\
\text { masyarakat dalam } \\
\text { mengakses } \\
\text { layanan publik }\end{array}$ & $\begin{array}{l}\text { Layanan informasi } \\
\text { lokasi layanan } \\
\text { publik seperti } \\
\text { Tempat Ibadah, } \\
\text { Informasi Travel, } \\
\text { Rumah Sakit, Hotel, } \\
\text { Bank, Tempat } \\
\text { Belajar dan kantor. } \\
\text { Diharapkan } \\
\text { informasi tersebut } \\
\text { dapat } \\
\text { mengefisiensikan } \\
\text { waktu dan biaya } \\
\text { masyarakat dalam } \\
\text { mengakses layanan } \\
\text { publik }\end{array}$ & $\begin{array}{l}\text { Sejumlah layanan } \\
\text { yang ada tentunya } \\
\text { akan meningkatkan } \\
\text { kecepatan, } \\
\text { ketepatan dan } \\
\text { kemudahan. }\end{array}$ & $\begin{array}{l}\text { Sistem Layanan } \\
\text { Pengadaan Secara } \\
\text { Elektronik (LPSE) } \\
\text { cukup } \\
\text { memberikan } \\
\text { informasi up to } \\
\text { date namun } \\
\text { mayoritas } \\
\text { pengusaha asli } \\
\text { Papua belum } \\
\text { semua } \\
\text { memanfaatkan } \\
\text { fasilitas ini karena } \\
\text { tidak menguasai } \\
\text { TIK, dengan } \\
\text { demikian selama } \\
\text { ini rata-rata } \\
\text { diakses oleh } \\
\text { pengusaha non asli } \\
\text { Papua }\end{array}$ \\
\hline
\end{tabular}


Tabel 4. Evaluasi Situs Web eGovernment Sisi Ekonomi

\begin{tabular}{|c|c|c|c|c|c|}
\hline & $\begin{array}{l}\text { Surabaya } \\
\end{array}$ & Medan & Banjarmasin & Makassar & Jayapura \\
\hline Ekonomi & $\begin{array}{l}\text { Informasi investasi dan } \\
\text { perekonomian cukup } \\
\text { tersedia dan dapat } \\
\text { membantu warga yang } \\
\text { dalam pelayanan dan } \\
\text { informasi }\end{array}$ & $\begin{array}{l}\text { Informasi investasi } \\
\text { dan perekonomian } \\
\text { cukup tersedia }\end{array}$ & $\begin{array}{l}\text { Belum } \\
\text { menampilkan } \\
\text { informasi yang } \\
\text { cukup mengenai } \\
\text { perkonomian dan } \\
\text { peluang investasi di } \\
\text { Kota Banjarmasin }\end{array}$ & $\begin{array}{l}\text { Informasi investasi } \\
\text { dan perekonomian } \\
\text { cukup tersedia }\end{array}$ & $\begin{array}{l}\text { Belum } \\
\text { menampilkan } \\
\text { informasi ekonomi } \\
\text { dan potensi } \\
\text { investasi }\end{array}$ \\
\hline
\end{tabular}

Tabel 5. Evaluasi Situs Web eGovernment Sisi Aspirasi

\begin{tabular}{|c|c|c|c|c|c|}
\hline & Surabaya & Medan & Banjarmasin & Makassar & Jayapura \\
\hline Aspirasi & $\begin{array}{l}\text { Membangun media } \\
\text { center, dengan } \\
\text { memanfaatkan sejumlah } \\
\text { fasilitas informasi, yakni } \\
\text { melalui media sosial, } \\
\text { email, telephone, portal } \\
\text { aspirasi, dsb. }\end{array}$ & $\begin{array}{l}\text { Jejak pendapat } \\
\text { warga diakomodir } \\
\text { di Situs Web, } \\
\text { terdapat forum } \\
\text { warga untuk } \\
\text { menyalurkan } \\
\text { aspirasi }\end{array}$ & $\begin{array}{l}\text { Fasilitas untuk } \\
\text { menjaring aspirasi } \\
\text { warga belum } \\
\text { tersedia, hanya } \\
\text { adanya buku tamu } \\
\text { dan halaman kontak } \\
\text { di Situs Web namun } \\
\text { itupun hanya } \\
\text { sebatas formalitas } \\
\text { dalam sebuah web, } \\
\text { artinya tidak ada } \\
\text { layanan aspirasi }\end{array}$ & $\begin{array}{l}\text { Tersedia fasilitas } \\
\text { penyampaian } \\
\text { aspirasi, terutama } \\
\text { melalui sistem } \\
\text { eSibuntulu. }\end{array}$ & $\begin{array}{l}\text { Jejak pendapat } \\
\text { warga diakomodir } \\
\text { di Situs Web, } \\
\text { terdapat forum } \\
\text { warga untuk } \\
\text { menyalurkan } \\
\text { aspirasi namun } \\
\text { hanya sebatas } \\
\text { hiasan, belum ada } \\
\text { interaksi }\end{array}$ \\
\hline
\end{tabular}

Tabel 6. Evaluasi Situs Web eGovernment Sisi Tampilan

\begin{tabular}{|c|c|c|c|c|c|}
\hline & Surabaya & Medan & Banjarmasin & Makassar & Jayapura \\
\hline Tampilan & $\begin{array}{l}\text { Navigasi mudah, warna } \\
\text { cukup menunjukkan } \\
\text { identitas, informasi } \\
\text { ditampilkan dengan cara } \\
\text { yang lebih 'segar' }\end{array}$ & $\begin{array}{l}\text { Tampilan dan } \\
\text { navigasi masih } \\
\text { cukup baik dan } \\
\text { mudah } \\
\text { menampilkan link } \\
\text { pada Situs Web } \\
\text { SKPD }\end{array}$ & $\begin{array}{l}\text { Sudah cukup } \\
\text { memberikan } \\
\text { kemudahan dalam } \\
\text { navigasi }\end{array}$ & $\begin{array}{l}\text { Cukup memberikan } \\
\text { kemudahan dalam } \\
\text { navigasi }\end{array}$ & $\begin{array}{l}\text { Sudah cukup } \\
\text { memberikan } \\
\text { kemudahan dalam } \\
\text { navigasi Situs } \\
\text { Web walaupun } \\
\text { menu dan isi } \\
\text { kontennya belum } \\
\text { cukup }\end{array}$ \\
\hline
\end{tabular}

Tabel 7. Evaluasi Situs Web eGovernment Sisi Update

\begin{tabular}{|c|c|c|c|c|c|}
\hline & Surabaya & Medan & Banjarmasin & Makassar & Jayapura \\
\hline Update & $\begin{array}{l}\text { Cukup update dalam } \\
\text { memberikan informasi }\end{array}$ & $\begin{array}{l}\text { Cukup update } \\
\text { informasi layanan } \\
\text { dan berita-berita } \\
\text { aktivitas } \\
\text { pemerintahan }\end{array}$ & $\begin{array}{l}\text { Cukup update } \\
\text { dalam memberikan } \\
\text { informasi dan } \\
\text { layanan }\end{array}$ & $\begin{array}{l}\text { Cukup update } \\
\text { dalam memberikan } \\
\text { informasi }\end{array}$ & $\begin{array}{l}\text { Belum cukup } \\
\text { update dalam } \\
\text { memberikan } \\
\text { informasi }\end{array}$ \\
\hline
\end{tabular}

Tabel 8. Evaluasi Situs Web eGovernment Sisi Pencapaian Tujuan eGovernment (World Bank)

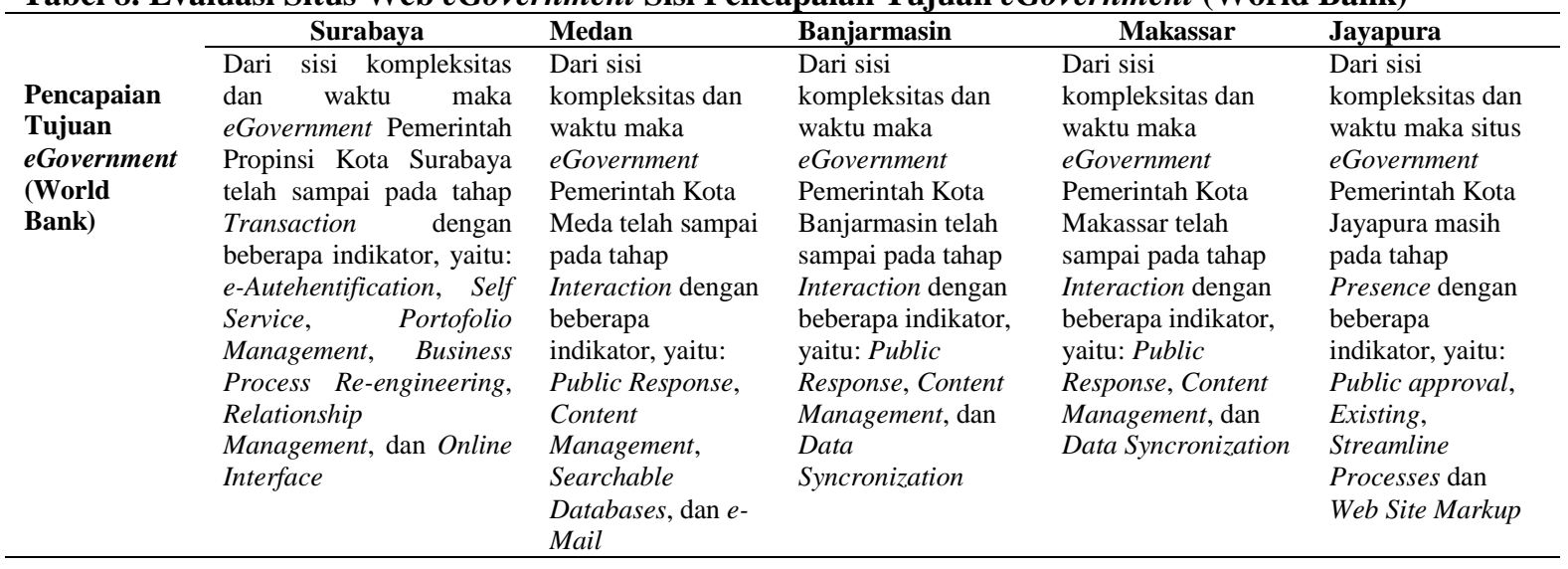


Evaluasi terhadap setiap variable pada Tabel 1 sampai dengan Tabel 8, dapat dijelaskan sebagai berikut: (1) Aspek Transparan, semua kota memasukkan laporan pengelolaan anggaran dan rencana program di situs web-nya (aspek transparansinya sudah baik) kecuali Kota Jayapura. (2) Aspek layanan, kota Surabaya jauh lebih baik karena mempunyai banyak layanan, yang memudahkan masyarakat untuk bertransaksi secara online, sementara kota Medan, Banjarmasin, Makasar hanya sebatas informasi prosedur layanan (masih manual), sedangkan Jayapura belum ada layanan maupun informasi prosedur layanan. (3) Aspek efisiensi, Kota Surabaya tentu jauh lebih baik dibanding kota lainnya karena tersedia beberapa layanan yang dilakukan secara online, sehingga lebih cepat, mudah dan murah. Sedangkan kota lainnya walaupun mendapat informasi melalui Situs Web mereka tetap melakukan transaksi secara manual di kantor pemerintahan, cara ini tentu membuang waktu, tenaga dan biaya lebih besar. (4) Aspek Ekonomi, Kota Surabaya, Banjarmasin dan Makasar menyediakan informasi mengenai potensi ekonomi dan peluang investasi sedangkan Kota Banjarmasin dan Jayapura belum menampilkan informasi yang cukup. (5) Aspek Aspirasi, Kota Surabaya, Makasar dan Medan tersedia fasilitas aspirasi, namun dalam pemanfaatannya Kota Surabaya jauh lebih baik jika dilihat dari pemanfaatannya, sedangkan untuk kota Banjarmasin dan Jayapura fasilitas untuk menjaring aspirasi warga belum tersedia, hanya adanya buku tamu dan halaman kontak di Situs Web tetapi itupun hanya sebatas formalitas dalam sebuah web. (6) Aspek Tampilan, semua Kota cukup baik, tetapi kota Surabaya jauh lebih 'segar', dari tata letak maupun warna. (7) Aspek Update, semua kota selalu update berita tentang aktivitas pemerintahan, kecuali kota Jayapura. (8) Aspek Pencapaian Tujuan eGovernment (World Bank, 2002) terlihat bahwa Kota Surabaya saat ini telah sampai pada tahap transaski, Kota Medan, Kota Banjarmasin dan Kota Makassar berada pada tahap interaksi dan Kota Jayapura berada pada tahap kehadiran. Hal tersebut juga menunjukkan bahwa sejumlah daerah yang menjadi objek kajian ini belum sampai pada tahap transformation, sehingga dibutuhkan keseriusan dan komitmen dari setiap daerah untuk mengembangkan eGovernment. Hasil evaluasi ini dapat dijadikan juga sebagai bahan pembanding untuk melihat sejauhmana implementasi eGovernment di daerah-daerah maju mewakili setiap pulau di Indonesia. Gambaran yang didapatkan dari hasil evaluasi ini sama dengan hasil evaluasi PeGi selama ini, yang sempat dikaji pada pembahasan sebelumnya bahwa peringkat terbaik eGovernment sejauh ini masih didominasi oleh pemerintahan di Pulau Jawa, sedangkan pulau lainnya masih sangat kurang.

Kurang optimalnya eGovernment disejumlah daerah tersebut tidak hanya dilihat dari aspekaspek yang dievaluasi ini, biasanya pembangunan dan pengembangan eGovernment jauh lebih luas, oleh karena itu rumusan persoalan maupun solusi yang ditawarkan juga harus lebih luas pula. Misalnya secara skala nasional kajian Kementerian Komunikasi dan Informasi menyimpulkan bahwa mayoritas situs Pemerintah Pusat dan Pemerintah Daerah masih berada pada tingkat persiapan (pertama) apabila ditinjau dari sejumlah aspek (Kurniawan, 2006:4), yakni: (1) Leadership: Kurangnya perhatian pimpinan dalama implementasi eGovernment. Para pimpinan lebih banyak fokus pada hal-hal mendasar, seperti pendidikan, kesehatan, dan infrastruktur karena aspek-aspek tersebut belum dibangun secara merata sehingga dibutuhkan perhatian serius. Di sisi lain, pimpinan belum menyadari akan pentingnya pemanfaatan teknologi informasi dalam pelayanan publik. (2) Infrastruktur Jaringan Informasi: secara umum memang masih belum tersebar secara merata. Misalnya di Kota Jayapura jaringan internet masih terbatas karena infrastruktur jaringan internet masih menggunakan VSAT, sehingga cuaca yang tidak menentu di Papua membuat perangkat cepat rusak. Kalaupun tersedia sejumlah fasilitas pendukung, harganya masih relatif mahal. (3) Pengelolaan Informasi: kualitas dan keamanan pengelolaan informasi yang kurang karena tidak didukung dengan infratruktur dan SDM yang handal. (4) Lingkungan Bisnis: kondisi pasar, perdagangan, dan regulasi yang membentuk konteks perkembangan bisnis teknologi informasi semakin berkembang pesat namun tidak diiringi dengan upaya-upaya pemerintah dan masyarakat dalam impementasi eGovernment. (5) Masyarakat dan Sumber Daya Manusia: 
Pemerintah umumnya jarang memiliki SDM yang handal di bidang teknologi informasi. SDM yang handal ini biasanya ada di lingkungan bisnis/industri. Kekurangan SDM ini menjadi salah satu penghambat implementasi dari eGovernment. Misalnya di Kota Jayapura banyak masyarakat yang belum melek IT, hal ini karena internet baru berkembang di Papua mulai tahun 2007 sehingga belum merata ke seluruh komponen masyarakat, sekarang lebih banyak yang akses internet adalah para pelajar dan mahasiswa, sama halnya terjadi disejumlah daerah misalnya di Kalimantan, NTT, dan Papua. Dengan melihat kepada kondisi di atas, maka tantangan yang muncul kemudian adalah bagaimana meningkatkan penerapan eGovernment di masa datang menjadi lebih memadai sehingga tidak memungkinkan lagi adanya tahapan pelayanan yang memerlukan pertemuan tatap muka antara masyarakat dengan penyedia pelayanan publik. Ketiadaan tatap muka dapat meminimalisir dan meniadakan aktivitas-aktivitas rent seeking.

Tantangan dan hambatan dalam impelementasi eGovernment di Indonesia secara umum mengalami hal yang sama sehingga penulis mengutip beberapa rekomendasi pemecahan masalah (Kurniawan, 2006: 4), antara lain: (1) Untuk hambatan di bidang regulasi dan pedoman penyelenggaran situs web pemda maka pemerintah pusat perlu membuat master plan dan grand strategy eGovernment yang dituangkan dalam undang-undang atau peraturan pemerintah beserta petunjuk pelaksanaan teknisnya karena implementasi membutuhkan tindakan dan penyediaan sarana dan bukan hanya konsep belaka. (2) Untuk hambatan SDM maka perlu dilakukan pendidikan dan pelatihan SDM di bidang teknologi informasi dan komunikasi yang terintegarsi. (3) Dalam hal keterbatasan sarana dan prasarana; maka diperlukan suatu solusi dalam bentuk kebijakan pemerintah untuk merangkul pihak swasta khususnya provider ITC dalam bentuk kerjasama terpadu yang tentunya menguntungkan ke dua belah pihak. Sebagai contoh misalnya MOU yang dibuat oleh pemerintah dengan pihak Microsoft yang menuangkan kebijakan bahwa akan dilakukan pemutihan bagi aplikasi software yang "bukan resmi" yang digunakan lembaga pemerintah adalah merupakan terobosan dalam mengatasi infrastruktur yang mahal. Selain itu, secara teknis pihak pemerintah daerah perlu membuat masterplan eGovernment yang bisa melibatkan semua satker yang mencakup aspek pembangunan infrastruktur, aplikasi, sumber daya manusia, perundang-undangan dan anggaran. (4) Untuk mengatasi belum meratanya literacy masyarakat tentang penggunaan eGovernment.

Untuk mengatasi belum meratanya literacy diperlukan strategi sosialisasi kepada masyarakat dengan beberapa tahapan yaitu: (a) Tahapan sosialisasi yang pertama adalah ditujukan kepada pimpinan lembaga pemerintah. Karena secara kultur faktor pemimpin sangat memegang peranan dalam implementasi eGovernment. Banyak contoh keberhasilan pelaksanaan eGovernment di berbagai negara, daerah atau kantor pemerintah disebabkan karena faktor skill dan kepedulian manajemen para pemimpinnya. (b)Tahapan kedua adalah memberikan penekanan dalam sosialisasi eGovernment di kalangan para pimpinan tentang manfaat yang bisa diperoleh dari penggunaan ICT dalam tata pemerintahan. Baik itu dari segi politis, ekonomi, produktivitas kerja pegawai dan juga image di mata masyarakat. (c) Tahapan ketiga, adalah melibatkan semua bagian dalam lembaga pemerintah termasuk Dewan Perwakilan Rakyat (DPR) dalam merumuskan dan membuat rencana induk (masterplan) pelaksanaan eGovernment daerah dan instansi. Keterlibatan DPR memiliki peran penting dalam kesuksesan pembangunan eGovernment semua elemen pemerintahan harus terlibat di dalamnya. (d) Tahapan keempat dalam sosialisasi eGovernment adalah memberikan brand awarness kepada para masyarakat luas tentang manfaat dan kegunaan bentuk-bentuk layanan dalam eGovernment. Mengingat beragamnya status sosial dan ekonomi masyarakat maka yang pertama diberikan penekanan sosialisasi adalah golongan masyarakat yang memiliki status sosial ekonomi menengah ke atas terlebih dahulu, karena mereka lebih dekat dengan teknologi internet dan konsep eGovernment. Selain itu cara ini juga akan mampu menjadikan mereka untuk menjadi stimulan pendorong bagi golongan masyarakat lain tentang manfaat dan kegunaan eGovernment. 


\section{Kesimpulan}

Berdasarkan pembahasan dan analisis implementasi eGovernment pada Situs Web Pemerintah Kota Surabaya, Kota Medan, Kota Banjarmasin, Kota Makassar dan Kota Jayapura terhadap aspek transparansi, layanan, efisiensi, ekonomi, aspirasi, tampilan, update, dan tahapan pencapaian tujuan eGovernment dapat disimpulkan bahwa: Kota Surabaya jauh lebih baik dibanding Kota-kota lainnya. Hasil ini sama dengan evaluasi PeGi dari tahun 2012-2014 bahwa dalam pemeringkatan Situs Web eGovernment selama ini hanya didominasi oleh pemerintahan di Pulau Jawa. Untuk itu, saran pengembangan kedepan adalah perlu dilakukan penyempurnaan konten situs Web, namun sebelumnya aspek E-Leadership, Infrastruktur Jaringan Informasi, Pengelolaan Informasi, Lingkungan Bisnis, Masyarakat dan Sumber Daya Manusia dapat dirumuskan dengan baik dalam bentuk Rencana Strategis agar pengembangan dan implementasinya dilakukan secara menyeluruh dan tepat sasaran.

\section{Referensi}

Convelo G. Cevilla. 1993. Pengantar Metode Penelitian. Jakarta: Universitas Indonesia

Ditjen APTIKA KEMKOMINFO RI. 2014. Pemeringkatan e-Government Indonesia (PeGi). (Online), (http://pegi.layanan.go.id/tabel-hasil-pegi-4/, diakses 26 Mei 2015)

Gupta, M.P. 2004. Towards E-government: Management Challenges. New Delhi: McGraw-Hill Publishing Company.

Hartono, D. U., \& Mulyanto, E. 2010. Electronic Government Pemberdayaan Pemerintahan dan Potensi Desa Berbasis Web. Jurnal Teknologi Informasi, 6(1).

Hermana, B., \& Silfianti, W. 2011. Evaluating e-government implementation by local government: digital divide in internet based public services in Indonesia. International Journal of Business and Social Science, 2(3), 156-163.

Holle, Erick S, 2011. Pelayanan Publik Melalui Electronic Government: Upaya Meminimalisir Praktek Maladministrasi Dalam Meningkatan Public Service. Jurnal Sasi, 17(3).

Indrajit, Richardus Eko. 2006. Electronic Government (Strategi Pembangunan dan Pengembangan Sistem Pelayanan Publik Berbasis Teknologi Digital). Yogyakarta: ANDI.

Indrajit, Richardus Eko 2002. Membangun Aplikasi eGovernment. Jakarta: PT Elek Media Komputindo.

Inpres No. 3 Tahun 2003 tentang Kebijakan dan Strategi Nasional Pengembangan eGovernment

Irawan, C. 2012. Evaluasi Kualitas Website Pemerintah Daerah Dengan Menggunakan Webqual (Studi Kasus Pada Kabupaten Ogan Ilir). Jurnal Sistem Informasi, 4(2).

Kurniawan, Teguh. 2006. Hambatan dan Tantangan dalam Mewujudkan Good Governance melalui Penerapan eGovernment di Indonesia. Prosiding Konferensi Nasional Sistem Informasi 2006. Bandung: Penerbit Informatika.

Mardalis, 1999. Metode Penelitian Suatu Pendekatan Proposal. Jakarta: Bumi Aksara

Rokhman, A. 2008. Potret dan hambatan e-government Indonesia. Jurnal Inovasi, Persatuan Pelajar Indonesia (PPI) Jepang, 11, 60.

Rusli, Alexander. 2004. Telematika Indonesia: Kebijakan dan Perkembangan. Jakarta: Tim Koordinasi Telematika Indonesia Kementerian Komunikasi dan Informasi Republik Indonesia.

Sitokdana, Melkior, 2014. Evaluasi Implementasi Situs eGovernment Kota Jayapura Provinsi Papua. Artikel (Online) (http://komapo.org/index.php/karya-ilmiah/48-karya-ilmiah/671evaluasi-implementasi-situs-e-Government-kota-jayapura-provinsi-papua, diakses 21 April 2015).

Sosiawan, Edwi, Arief, 2008. Tantangan Dan Hambatan Dalam Implementasi eGovernment Di Indonesia. Prosiding Seminar Nasional Informatika UPN "Veteran" Yogyakarta, 24 Mei 2008. Hal 99-108 
300 Jurnal Buana Informatika, Volume 6, Nomor 4, Oktober 2015: 289-300

Sugiyono, 2009. Metode Penelitian Kuantitatif Kualitatif dan R\&D, Bandung: Alfabeta, Cet. Ke 8, h. 137

Tasmil, T. 2013. Pemeringkatan E-Government di Kota Makassar. Jurnal Penelitian Komunikasi, Informatika dan Media Massa, 16(3), 187-196.

The World Bank, 2002. New-Economy Sector Study, Electronic Government and Governance: Lesson for Argentina. 